\title{
HUBUNGAN PEMBERIAN NUTRISI PADA BALITA IBU BEKERJA DENGAN STATUS GIZI BALITA DI WILAYAH KERJA POSYANDU CUT NYAK DIN DESA MUNGKUNG KECAMATAN LOCERET KABUPATEN NGANJUK
}

\author{
Lusia Wahyuning Tyas ${ }^{1}$, Luhung Tantyoko ${ }^{2}$ \\ ${ }^{1}$ Dosen STIKesSatria Bhakti Nganjuk, ${ }^{2}$ Mahasiswa STIKesSatria Bhakti Nganjuk, \\ Email : lusiawahyuningtyas44@gmail.com
}

\begin{abstract}
Background.Toddlers are the age group most often suffer from malnutrition. One of the factors that influence nutritional status of children is nutrition intake. In working mothers often lead to the mother did not have time to provide and pay attention to mother's toddler's food. This study aims to determine the relationship of nutrition in toddlers working mother with nutritional status of children under five years in posyadu work area Cut Nyak Din Village MungkungLoceretNganjuk District. Method.Design of correlation using Cross Sectional.on 7-9 May 2017. The Population of 120 mothers who have a toddler and the sample of 31 respondents with sampling technique Purposive Sampling.Independent variable is the provision of nutrition using the questionnaire instrument while, dependent variable is the nutritional status using the data analysis dacin scale with Spearman Rank test with $\alpha=$ 0.05. Results. The results of the study most of the 17 respondents (54.9) have good category nutrition and most of $21(67.7 \%)$ of respondents have good nutritional status category. Where almost $15(48,4)$ of respondents have good category nutrition and toddler status of good nutrition status category. The statistic obtained result $\mathrm{p}$ value $=0,000$ ( $\mathrm{p}$ value $<\mathrm{a}$ ) and $\mathrm{r}=$ $0,529 \mathrm{Ha}$ accepted mean there is relation between giving of nutrition at toddler working mother with child nutrition status at posyandu work area Cut Nyak Din Village MungkungLoceretNganjuk District with level of moderate. Conclusion. Working mothers should be able to divide the time between work outside the home with the attention that must be given to the toddler, the mother can apply mother's nutritional knowledge to the attitude of feeding to the toddler and the toddler should get the food in accordance with the nutritional adequacy rate.
\end{abstract}

\section{Keywords: nutrition, nutrition status, toddler, working mother}

\section{PENDAHULUAN}

Masa balita merupakan fase terpenting dalam membangun pondasi pertumbuhan dan perkembangan manusia. Masa anak usia 1-5 tahun juga kelompok yang menunjukan pertumbuhan badan yang pesat, sehingga memerlukan zat zat gizi yang tinggi setiap kg berat badannya. Anak balita ini justru merupakan kelompok umur yang paling sering menderita akibat kekurangan gizi (KKP) (Sediaoetama, 2008). Kekurangan gizi pada masa ini dapat menimbulkan gangguan tumbuh kembang secara fisik, mental, social dan intelektual yang sifatnya menetap dan terus dibawa sampai anak menjadi dewasa. Secara lebih spesifik, kekurangan gizi dapat menyebabkan keterlambatan pertumbuhan badan, lebih penting lagi keterlambatan perkembangan otak dan dapat pula 
terjadinya penurunan atau rendahnya daya tahan tubuh terhadap penyakit infeksi. Pada masa ini juga, anak masih benar-benar tergantung pada perawatan dan pengasuhan oleh ibunya. Pengasuhan kesehatan dan makanan pada masa balita sangatlah penting untuk perkembangan anak (Santoso, 2005 dalam Lubis, 2008).

Beberapa kondisi yang salah satunya adalah ibu sudah bekerja penuh, sehingga tidak lagi dapat memberikan perhatian dan memberikan asupan nutrisi yang terbaik kepada anak balita, apalagi mengurusnya (Sedia oetama, 1987). Pada keadaan seperti ini dengan orang tua bekerja, yang seharusnya orang tua khususnya ibu merawat dan memperhatikan asupan nutrisi anaknya. Dengan orang tua bekerja anak akan menjadi terlantar dan orang tua tidak memperhatikan pemberian nutrisi yang diberikannya untuk anaknya, tentu nyajika mempunyai anak balita yang belum mampu memenuhi kebutuhan nutrisinya sendiri tanpa dibantu orang tua, iniakan menjadi masalah untuk kebutuhan gizi anak balita (Bumi, 2005). Hasil wawancara dari $10 \mathrm{ibu}$ bekerja pada tanggal 7 Pebruari 20174 ibu mengatakan selalu menyiapkan makanan untuk anak sebelum berangkat bekerja dan 6 ibu mengatakan balitanya dititipkan kekeluarga makan karena tidak sempat menyiapkan makanan.
Badan kesehatan dunia (WHO) memperkirakan bahwa 54\% kematian anak disebabkan oleh keadaan gizi yang buruk. Sementara masalah gizi di Indonesia mengakibatkan lebih dari $80 \%$ kematian anak (WHO, 2011). Dapat disimpulkan bahwa pemberian makanan dan gizi di Indonesia masih sangat buruk. Data Riskesdas (2013) merangkum bahwa secara nasional prevalensi status gizi anak balita menurut ketiga indeks $\mathrm{BB} / \mathrm{U}$. Terlihat prevalensi gizi buruk dan gizi kurang meningkat dari tahun 2007 ketahun 2013. Sedangkan di Kabupaten Nganjuk menurut Profil Kesehatan Jawa Timur (2012), dari 62.610 balita yang ditimbang masih ada $0,79 \%$ menderita gizi lebih, 7,66 \% menderita gizi kurang, dan 1,32 \% mengalami gizi buruk. Jumlah ini masih lebih tinggi dibandingkan rata-rata status gizi pada balita di Jawa timur 5,71\% untuk gizi kurang dan 1,15\% untuk gizi buruk (Badan Penelitian Dan Pengembangan Kesehatan Kementrian Kesehatan RI dan Dinas Kesehatan Provinsi Jawa Timur, 2013).

Pada data Dinas Kesehatan Kabupaten Nganjuk tahun (2016) merangkum angka kejadian tertinggi berat badan kurang balita dengan 8,14\% anak laki-laki dan 9,01\% anak perempuan yang terjadi di Kecamatan Loceret Kabupaten nganjuk. Jumlah ini masih lebih tinggi dibandingkan rata-rata 
angka kejadian gizi kurang kurang diseluruh Kabupaten nganjuk untuk lakilaki 6\% dan untuk perempuan 6,51\%. Pada posyandu Cut Nyak Din Desa Mungkung Kecamatan Loceret Kabupaten Nganjuk terdapat 120 balita yang terdaftar dalam posyandu. Dari 120 balita terdapat 28 balita mengalami gizi kurang.

Pada ibu yang bekerja beban yang ditanggung lebih berat, diantaranya harus mencari nafkah dan mengurus rumah. Kegiatan yang bertambah menyebabkan waktu yang disediakan untuk mengurus anak atau sekedar menyiapkan makananakan berkurang. Pada ibu yang bekerja biasanya anak balita akan kurang mendapat perhatian. Kurangnya perhatian akan berakibat negative terhadap status gizi anak apabila makanan anak balita tidak diperhatikan. Fenomena yang demikian sangat berpengaruh terhadap pemberian asupan nutrisi kepada anak yang akhirnya akan menyebabkan perubahan status gizi (Bumi, 2005).

Balita masih belum bisa mengurus dirinya sendiri dengan baik dan belum bisa berusaha mendapatkan sendiri apa yang diperlukannya untuk makanannya. Balita sangat tergantung pada ibu atau pengasuhnya dalam memenuhi kebutuhannya. Menurut Suhardjo (2003) dalam (bumi, 2005). Pada masa bayi dan balita, orang tua harus selalu memperhatikan kualitas dan kuantitas makanan yang dikonsumsi oleh anak dengan membiasakan pola makan yang seimbang dan teratur setiap hari, sesuai dengan tingkat kecukupannya. Berdasarkan uraian di atas, peneliti tertarik untuk mengadakan penelitian dengan judul "Hubungan Pemberian Nutrisi Pada Balita Ibu Bekerja Dengan Status Gizi Balita di Posyandu Cut Nyak Din Desa Mungkung Kecamatan Loceret Kabupaten Nganjuk".

\section{METODE}

Penelitian ini menggunakan desain Corelasional dengan pendekatan secara cross sectional. Pada tanggal tanggal 7-9 Mei 2019 di wilayah kerja Posyandu Cut Nyak Din Desa Mungkung Kecamatan Loceret Kabupaten Nganjuk. Dengan populasi 34 responden. Sampel penelitian ini sebanyak 31 responden yang didapatkan dengan tehnik Purposive sampling dengan kriteria inklusi yaitu Bersedia menjadi responden, ibu yang memiliki kegiatan/bekerja yang mengharuskan ibu meninggalkan rumah selama 6 jam, ibu dengan anak usia balita Dalam penelitian ini variabel independen adalah pemberian nutrisi pada balita ibu bekerja, variabel dependen adalah status gizi balita yang diobservasi menggunakan kuesioner dan Timbangan dacindantabel WHO NCHS. 
Data dianalisis dengan uji statistik Coefficient Contingency dengan $\alpha=0,05$.

\section{Hasil Penelitian}

a. Pemberian nutrisi pada balita ibu bekerja di wilayah kerja posyandu Cut Nyak Din Desa Mungkung Kecamatan Loceret Kabupaten Nganjuk.

Tabel 1 distribusi frekuensi pemberian nutrisi pada balita ibu bekerja di wilayah kerja posyandu Cut Nyak Din Desa Mungkung Kecamatan Loceret Kabupaten Nganjuk 7-9 Mei 2019

\begin{tabular}{lcc}
\hline Kategori & Frekuensi & Presentase (\%) \\
\hline Baik17 & 54,8 & 29,0 \\
Cukup & 9 & \\
Kurang56,1 & & \\
\hline Total31 & 100,0 & \\
\hline
\end{tabular}

$\begin{array}{lllll}\text { Bedasarkan data padatabel } 1 & \text { dapatdiketahuibahwadari } 31\end{array}$

respondensebagianbesarmemilikikategoribaikdalampemberiannutrisipadaanakbali tayaitusebanyak 17 orang $(54,8 \%)$.

b. Status gizi balita di wilayah kerja posyandu Cut Nyak Din Desa Mungkung Kecamatan Loceret Kabupaten Nganjuk.

Tabel 2 distribusi frekuensi status gizi balita di wilayah kerja posyandu Cut Nyak Din Desa Mungkung Kecamatan Loceret Kabupaten Nganjuk 7-9 Mei 2019

\begin{tabular}{ccc}
\hline Kategori & Frekuensi & Presentase (\%) \\
\hline Gizi lebih & 0 & 0 \\
Gizi baik & 22 & 71.0
\end{tabular}

Gizi kurang929,0

Gizi buruk00

Total $31 \quad 100,0$

Berdasarkan data dari tabel 2 dapat diketahu bahwa dari 31 responden sebagian besar memiliki status gizi baik yaitu sebanyak 21 (67,7\%).

c. Pemberian nutrisi pada balita ibu bekerja dengan status gizi balita di wilayah kerja posyandu Cut Nyak Din Desa Mungkung Kecamatan Loceret Kabupaten Nganjuk.

Tabel 3 Tabulasi silang Hubungan pemberian nutrisi pada balita ibu bekerja dengan status gizi balita di wilayah kerja posyandu Cut Nyak Din Desa Mungkung Kecamatan Loceret Kabupaten Nganjuk 7-9 Mei 2019 


\begin{tabular}{|c|c|c|c|c|c|c|c|c|c|c|}
\hline \multirow{3}{*}{$\begin{array}{c}\text { Pemberian } \\
\text { nutrisi }\end{array}$} & \multicolumn{8}{|c|}{ Status gizi } & \multicolumn{2}{|c|}{ Total } \\
\hline & \multicolumn{2}{|c|}{$\begin{array}{c}\text { Gizi } \\
\text { Lebih }\end{array}$} & \multicolumn{2}{|c|}{$\begin{array}{l}\text { Gizi } \\
\text { Baik }\end{array}$} & \multicolumn{2}{|c|}{$\begin{array}{c}\text { Gizi } \\
\text { Kurang }\end{array}$} & \multicolumn{2}{|c|}{$\begin{array}{c}\text { Gizi } \\
\text { Buruk }\end{array}$} & \multirow[b]{2}{*}{ Jml } & \multirow[b]{2}{*}{$\%$} \\
\hline & Jml & $\%$ & Jml & $\%$ & Jml & $\%$ & $\mathrm{Jml}$ & $\%$ & & \\
\hline Baik & 0 & 0 & 15 & 48,4 & 2 & 6,5 & 0 & 0 & 17 & 54,9 \\
\hline Cukup & 0 & 0 & 7 & 22,6 & 3 & 9,6 & 0 & 0 & 10 & 29 \\
\hline Kurang & 0 & 0 & 0 & 0 & 4 & 12,9 & 0 & 0 & 4 & 16,1 \\
\hline Total & 0 & 0 & 22 & 71,0 & 9 & 29,0 & 0 & 0 & 31 & 100,0 \\
\hline $\begin{array}{l}\text { Hasil uji } s_{t} \\
\mathrm{r}=0,528\end{array}$ & 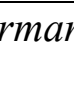 & & & & & & & & & \\
\hline
\end{tabular}

Berdasarkan tabel 3 menunjukan bahwa yaitu 15 (48,4\%) responden baik dalam pemberian nutrisi pada balitanya dengan balita mengalami status gizi baik yaitu 15 (48,4\%). Dengan memakai uji statisticSpearman Rank dengan a = 0,05 didapatkan nilai $p$ value $=0,002(\mathrm{p}$ value $\leq \mathrm{a})$ yang berarti Ha diterima atau ada hubungan antara pemberian nutrisi pada balita ibu bekerja dengan status gizi balita di wilayah kerja posyandu Cut Nyak Din Desa Mungkung Kecamatan Loceret Kabupaten Nganjuk dengan $r=0,528$ yaitu tingkat keeratan hubungan kategori sedang.

\section{PEMBAHASAN}

1. Pemberian nutrisi pada balita ibu bekerja diwilayah kerja posyandu Cut Nyak Din Desa Mungkung Kecamatan Loceret Kabupaten Nganjuk.

Berdasarkan penelitian dapat diketahui bahwa pemberian nutrisi pada balita ibu bekerja di wilayah kerja posyandu Cut Nyak Din Desa Mungkung Kecamatan Loceret Kabupaten Nganjuk sebagian besar memiliki kategori baik yaitu 17 responden $(54,8 \%)$. Hal ini dipengaruhi oleh faktor pendidikan didapatkan dari
17 responden tersebut berpendidikan perguruan tinggi sebanyak 5 responden dan SMA 8 responden. Hal ini dibuktikan dengan hasil uji koefisien kontingensip value $=0,000 \leq \alpha(0,05)$ selain itu pemberian nutrisi ini bisa dipengaruhi oleh ekonomi. Namun pada penelitian ini faktor ekonomi tidak terdapat hubungan, sehingga dapat dipastikan jika keluarga dengan pendapatan rendah tidak mampu memenuhi kebutuhannya, begitu sebaliknya. Apabila seseorang memiliki pendapatan yang tinggi maka dia dapat 
memenuhi kebutuhan akan makanannya (Gesissler, 2005 dalam Khairina, 2008). Berarti pendapatan akan berhubungan dengan daya beli keluarga seperti pendapat Soekirman (2000) dalam Kusumaningrum (2003) Daya beli keluarga biasanya dipengaruhi oleh faktor harga dan pendapatan keluarga. Daya beli keluarga dipengaruhi oleh ketersediaan bahan pangan keluarga berkurang sehingga konsumsi makanan juga berkurang. Sehingga memberikan dampak gangguan gizi .

Nutrisi adalah zat gizi yang dibutuhkan oleh tubuh untuk tumbuh dan berkembang. Jenis nutrisi yang diperlukan oleh tubuh adalah karbohidrat, lemak, protein, vitamin, mineral dan air (Supartini, 2004 dalam Sulistyorini 2009). Pada usia balita, anak-anak membutuhkan dukungan nutrisi yang lengkap untuk pertumbuhan dan perkembangan tubuh dan otak mereka. Masa balita adalah masa kritis, maka kebutuhan nutrisi bagi balita haruslah seimbang, baik dalam jumlah (porsi) maupun kandungan gizi. Pencapaian gizi seimbang pada balita akan membuat anak tumbuh cerdas, sehat serta tidak mudah terserang penyakit (Sutomo dan Anggraini, 2010). Menurut Sulistyoningsih (2011) dan (Khosman, 2006) dalam setyorini (2009) ada faktor yang mempengaruhi pemberian nutrisi salah satunya adalah pendidikan, dalam penelitian yang dilakukan menunjukan bahwa adanya hubungan antara pendidikan dengan pemberian nutrisi. Pendidikan sangat erat kaitanya dengan pengetahuan dengan rendahnya pendidikan akan mempengaruhi pengetahuan ibu. Dengan rendahnya pengetahuan semakin sulitnya ibu menangkap informasi mengenai nutrisi. Hal ini selaras dengan pendapat bumi (2005) pengetahuan ibu tentang gizi anak balitanya cukup berpengaruh terhadap tingkat pemberian nutrisi yang diperoleh dari konsumsi makan anak sehari-hari.

Pemberian nutrisi pada balita ibu bekerja berdasarkan hasil penelitian menunjukan dalam kategori baik salah satunya dipengaruhi oleh pendidikan ibu yang telah diungkap diatas. Dengan orang yang berpendidikan tinggi akan memiliki pengetahuan yang luas dan mudah dalam menerima informasi maupun pengetahuan. Dengan ibu yang berpengetahuan luas akan mengetahui nutrisi yang dibutuhkan oleh balitanya sehingga dengan demikian nutrisi balita akan terpenuhi dengan baik. Dalam distribusi responden berdasarkan pendidikan menunjukan hampir setengahnya berpendidikan SMP, 
sehingga kemampuan responden dalam memahami informasi yang didapatkan menjadi kurang.

2. Status gizi balita di wilayah kerja posyandu Cut Nyak Din Desa Mungkung Kecamatan Loceret Kabupaten Nganjuk.

Berdasarkan penelitiandapat diketahui bahwa status gizi balita di wilayah kerja posyandu Cut Nyak Din Desa Mungkung Kecamatan Loceret Kabupaten Nganjuk sebagian besar memiliki kategori status gizi baik yaitu 21 responden $(67,7)$. Hal ini dipengaruhi oleh faktor pendidikan ibu didapatkan dari 21 responden, 9 diantaranya berpendidikan SMP 7 responden berpendidikan SMA dan 5 responden berpendidikan perguruan tinggi. diketahui bahwa pendidikan memiliki hubungan dengan status gizi balita, hal ini dibuktikan dengan uji koefisien kontingensip value $=0,002 \leq \alpha(0,05)$.

Menurut Suhardjo, 2005 bahwa status gizi adalah kesehatan individuindividu / kelompok-kelompok yang ditentukan oleh derajat kebutuhan fisik akan energy dan zat-zat gizi lain yang diperoleh dari makanan yang dampak fisiknya diukur secara antopometri sedangkan balita merupakan salah satu kelompok yang rawan gizi. Oleh sebab itu pemberian makanan balita perlu diperhatikan, karena kebiasaan pemberian makanan yang tidak tepat sangat mempengaruhi pertumbuhan balita. Dari hasil statistic salah satu factor yang memiliki hubungan dengan status gizi balita adalah pendidikan ibu. Hal ini selaras dengan Siswanto (2010), Latar belakang pendidikan seseorang berhubungan dengan tangkap pengetahuan, jika tingkat pengetahuan ibu baik maka ibu akan lebih mudah menangkap informasi yang baik mengenai status gizi, maka diharapkan status gizi ibu dan anak juga baik.

Status gizi balita berdasarkan dari hasil penelitian dapat dikategorikan sebagian besar adalah status gizi baik yang salah satunya dipengaruhi oleh pendidikan ibu seperti yang telah diuraikan diatas tingkat pendidikan seseorang sangat erat kaitanya dengan pengetahuan. Dengan rendahnya tingkat pendidikan penggetahuan tentang keshatan dan gizi akan rendah hal ini akan sangat merugikan dan secara tidak langsung akan mengakibatkan masalah kurakurang gizi pada anak. Karena dengan rendahnya pengetahuan dari seorang ibu akan sulit menerima informasi yang baik tetang kesehatan gizi bagi anaknya dan secara tidak langsung ibu akan kurang mengerti apakah makanan yang diberikan oleh ibu 
sudah memenuhi kebutuhan nutrisi anaknya atau belum.

3. Hubungan pemberian nutrisi pada balita ibu bekerja dengan status gizi balita di wilayah kerja posyandu Cut Nyak Din Desa Mungkung Kecamatan Loceret Kabupaten Nganjuk.

Berdasarkan penelitian dapat diketahui bahwa dari 31 responden hampir setengahnya memiliki pemberian nutrisi baik dan status gizi balita gizi baik. Hasil uji statistik spearman rank nilai $p$ value $=0,002 \leq \alpha(0,05)$ yang berarti $\mathrm{H}_{\mathrm{a}}$ diterima yang berarti ada hubungan antara pemberian nutrisi pada balita ibu bekerja dengan status gizi balita di wilayah kerja posyandu Cut Nyak Din Desa Mungkung Kecamatan Loceret Kabupaten Nganjuk dengan keeratan hubungan $\mathrm{r}=0,528$ kategori sedang.

Status gizi merupakan faktor yang terdapat dalam level individu (level yang paling mikro). Faktor internal yang mempengaruhi status gizi antara lain asupan nutrisi dan infeksi. Penyebab langsung timbulnya masalah gizi kurang pada anak adalah konsumsi makanan dan penyakit infeksi (Soekirman, 2000 dalam Kusumaningrum, 2003). Asupan nutrisi berpengaruh terhadap status gizi seseorang. Status gizi baik atau status gizi optimal terjadi bila tubuh memperoleh cukup zat-zat gizi yang digunakan secara efisien, sehingga memungkinkan pertumbuhan fisik, perkembangan otak, kemampuan kerja dan kesehatan secara umum pada tingkat setinggi mungkin. Status gizi kurang terjadi bila tubuh mengalami kekurangan satu atau lebih zat esensial. Status gizi lebih terjadi bila tubuh memperoleh zat gizi dalam jumlah berlebih, sehingga menimbulkan efek toksik atau membahayakan (Almatsier, 2009 dalam Mariyam dan Purwani, 2013). Asupan nutrisi balita pada ibu tidak bekerja idealnya akan dapat lebih diperhatikan bila dibandingkan dengan ibu bekerja. sejalan dengan pendapat Nasedul (1996). Meskipun dari kelompok ibu bekerja, namun status gizi bisa dipengaruhi faktor lain antara lain ada infeksi dan aktivitas fisik. Seperti yang dikemukakan oleh Andriani dan Wirjatmadi (2012) bahwa usia 1 - 5 tahun merupakan usia dimana petumbuhannya tidak sepesat ketika masa bayi, dan terjadi peningkatan aktivitas. Hal ini sependapat dengan Sulistyorini (2009) mengatakan bahwa pengecualian ini disebabkan faktorfaktor yang berhubungan dengan status gizi balita tidak hanya status pekerjaan ibu saja, namun masih banyak faktorfaktor lain misalnya pendapatan 
keluarga, pendidikan ibu, budaya, pelayanan kesehatan, usia orang tua, kondisi fisik anak, infeksi, dan asupan makan. Adanya pengecualian pada hasil penelitian ini disebabkan ada faktor lain yang lebih dominan mempengaruhi status gizi balita dibandingkan status pekerjaan ibu.

Peran ibu sangatlah penting dalam pertumbuhan anak karena peran ibu untuk balita yang masih belum bisa mengurus dirinya sendiri dengan baik dan belum bisa berusaha mendapatkan sendiri apa yang diperlukan untuk makanannya. Balita masih sangat tergantung pada ibu dalam memenuhi kebutuhannya khususnya untuk kebutuhan nutrisi

\section{KESIMPULAN}

Berdasarkan data dan hasil penelitian yang telah dilakukan dapat diambil kesimpulan Pemberian nutrisi pada balita ibu bekerja di wilayah kerja Posyandu Cut Nyak Din Desa Mungkung Kecamatan Loceret Kabupaten Nganjuk sebagian besar memiliki kategori baik yaitu 17 responden $(54,8 \%)$. Status gizi balita di wilayah kerja posyandu Cut Nyak Din Desa Mungkung Kecamatan Loceret Kabupaten Nganjuk sebagian besar memiliki kategori status gizi baik yaitu 21 responden $(67,7)$. Pemberian nutrisi pada balita ibu bekerja berhubungan dengan status gizi balita di wilayah kerja posyandu Cut Nyak Din Desa Mungkung Kecamatan Loceret Kabupaten Nganjuk dengan nilai $p$ value $=0,002<\alpha 0,05$ dan nilai $\mathrm{r}=0,528$ menunjukan tingkat keeratan hubungan sedang

\section{SARAN}

Diharapkan institusi kesehatan lebih memperhatikan status gizi pada masyarakat terutama bagi balita yang rentan akan gizi dengan memberikan edukasi ataupun penyuluhan gizi.

\section{DAFTAR PUSTAKA}

Almatsier, S, 2001. Prinsip Dasar Ilmu Gizi. PT. Gramedia Pustaka Umum. Jakarta.

Arikunto, Suharsimi. (2010). Prosedur Penelitian Suatu Pendekatan Praktik. Jakarta: Rineka Cipta.

Bumi, Cindar, 2005. Pengaruh Ibu yang Bekerja Terhadap Status Gizi Anak Balita di Kelurahan Mangunwijan Kabupaten Demak. Fakultas Ilmu Keolahragaan Universitas Negeri Semarang.

Dahlan, M. Sopiyudin (2006). Statistik Untuk Kedokteran dan Kesehatan Uji Hipotesis dengan Menggunakan SPSS. Jakarta: PT. Arkans.

Dinas Kesehatan. 2013. Profil Kesehatan Provinsi Jawa Timur 
Dinas Kesehatan. 2016. Status Gizi Kabupaten Nganjuk. Nganjuk.

Endang Suwiji. (2006). Endang suwiji. Hubungan Pola Asuh Gizi Dengan Status Gizi Balita Usia 4-12 bulan.

Hidayat, A. Aziz Alimul. (2008). Metode Penelitian Keperawatan dan Teknik AnalisisData. Jakarta : Salemba Medika.

Kementrian Kesehatan RI. 2010. Keputusan Menteri Kesehatan Republik Indonesia Nomor: 1995/MENKES/SK/XII/2010 Tentang Standart Antopometri Penilaian Status Gizi Anak.

Kurnia, Vicky A. 2008. Hubungan Antara Status Pekerjaan Ibu Dengan Status Gizi Berdasarkan IMT Pada Pembantu Rumah Tangga Di Perumahan Duta Indah Bekasi. Skripsi. Fakultas Kesehatan Masyarakat Universitas Indonesia.

Lubis, Ritayani. 2008. Hubungan Pola Asuh Ibu dengan Status Gizi Anak Balita di Wilayah Kerja Pukesmas Pantai Cermin Kecamatan Tanjung Pura Kabupaten Langkat Tahun 2008. Skripsi. Fakultas Kesehatan Masyarakat Sumatra Utara.

Nursalam (2016). Metodologi Penelitian Ilmu Keperawatan: Pendekatan Praktis. Jakarta: Salemba Medika.

Purbasusila, Hamimah Dewi Antika Putri. 2016. Hubungan Pengetahuan Pola Asuh Makan dan Asupan zat Gizi pada Ibu Bekerja dan tidak Bekerja dengan Status Gizi Anak Usia 4 - 6 Tahun Di TK An- Nuur Desa Tosaren Kecamatan Pesantren Kota Kediri. Skripsi. Jurusan Gizi Politeknik Kesehatan Kemenkes Surabaya.
Riskesdas.2013. Badan Penelitian Dan Pengembangan Kesehatan Kementerian Kesehatan RI.

Sartika, Ratu Dewi.2010. An Analysis on The Usage of Health Service Related to Nutritional Status of Under-five Years Old Children Dept.Gizi Kesehatan Masyarakat UI.

Sediaoetama, Ahmad djaeni. 2008. Ilmu Gizi Untuk Mahasiswa Dan Profesi. Jakarta : PT. Dian Rakyat.

Sulistyorini, Etik. 2009. Hubungan Pekerjaan ibu Balita Terhadap Status Gizi Balita Di Posyandu Prima Sejahtera Desa Pandean Kecamatan Ngemplak Kabupaten Boyolali.

Supariasa, I Dewa Nyoman, Bachtiar Bakri, Ibnu Fajar, 2001. Penilaian Status Gizi. Jakarta: EGC.

Sutomo dan Anggraini, 2010. Menu Sehat dan Alami Untuk Batita Dan Balita. Jakarta: Demedia

Setiadi. (2013). Konsep dan Praktik Penulisan Riset Keperawatan. Yogyakarta: Graha Ilmu.

Suwiji.2016. Kebutuhan Nutrisi Pada Balita.

http://digilib.unimus.ac.id/files/disk1/1 16/jtptunimus-gdl-muksing2a2-5767-2babii.pdf. Diakses Pada Selasa, 3 Januari, 2016 1:52:29. 